\title{
Validation of Korean Version of Low Anterior Resection Syndrome Score Questionnaire
}

\author{
Chang Woo Kim ${ }^{1}$, Woon Kyung Jeong ${ }^{2}$, Gyung Mo Son ${ }^{3}$, Ik Yong Kim ${ }^{4}$, Ji Won Park ${ }^{5}$, Seung-Yong Jeong 5 , \\ Kyu Joo Park ${ }^{5}$, Suk-Hwan Lee ${ }^{1}$ \\ ${ }^{1}$ Department of Surgery, Kyung Hee University Hospital at Gangdong, Kyung Hee University School of Medicine, Seoul; ${ }^{2}$ Department of \\ Surgery, Keimyung University Dongsan Medical Center, Keimyung University School of Medicine, Daegu; ${ }^{3}$ Department of Surgery, Pusan \\ National University Yangsan Hospital, Pusan University College of Medicine, Yangsan; ${ }^{4}$ Department of Surgery, Wonju Severance Christian \\ Hospital, Yonsei University Wonju College of Medicine, Wonju; ${ }^{5}$ Department of Surgery, Seoul National University Hospital, Seoul National \\ University College of Medicine, Seoul, Korea
}

Purpose: Patients who undergo radical surgery for rectal cancer often experience low anterior resection syndrome (LARS). Symptoms of this syndrome include frequent bowel movements, gas incontinence, fecal incontinence, fragmentation, and urgency. The aim of this study was to investigate the convergent validity, discriminative validity, and reliability of the Korean version of the LARS score questionnaire.

Methods: The English LARS score questionnaire was translated into Korean using the forward-and-back translation method. A total of 146 patients who underwent radical surgery for rectal cancer answered the Korean version of the LARS score questionnaire including an anchor question assessing the impact of bowel function. Participants answered the questionnaire once more after 2 weeks.

Results: The Korean LARS score questionnaire showed high convergent validity in terms of high correlation between the LARS score and quality of life (perfect fit $55.5 \%$ vs. moderate fit $37.6 \%$ vs. no fit $6.8 \%$, respectively; P < 0.001 ). The LARS score also showed good discriminative validity between groups of patients differing by sex ( 29 for males vs. 25 for females; $\mathrm{P}=0.014$ ), tumor level ( 29 for $\leq 8 \mathrm{~cm}$ vs. 24 for $>8 \mathrm{~cm} ; \mathrm{P}=0.021$ ), and radiotherapy ( 32 for yes vs. 24 for no; $\mathrm{P}=0.001$ ). The LARS score also demonstrated high reliability at test-retest with no difference between scores at the first and second tests (intraclass correlation coefficient: Q1 $=0.932$; Q2 $=0.909, \mathrm{Q} 3=0.944, \mathrm{Q} 4=0.931$, and Q5 $=0.942 ; \mathrm{P}<0.001$, respectively).

Conclusion: The Korean version of the LARS score questionnaire has proven to be a valid and reliable tool for measuring LARS in Korean patients with rectal cancer.

Keywords: Low anterior resection syndrome; Rectal cancer; Quality of life; Validation; Questionnaire

Received: 22 May 2019 - Accepted: 1 August 2019

Correspondence to: Suk-Hwan Lee, M.D.

Department of Surgery, Kyung Hee University Hospital at Gangdong, Kyung Hee University School of Medicine, 892 Dongnam-ro, Gangdong-gu, Seoul 05278, Korea

Tel: +82-2-440-6134, Fax: +82-2-440-6073, E-mail: leeshdr@gmail.com ORCID: https://orcid.org/0000-0001-6470-8620

- This work was presented as an oral presentation at the 52nd Annual meeting of the Korean Society of Coloproctology, April 5, 2019, Jeju, Korea.

(C) 2020 The Korean Society of Coloproctology

This is an open-access article distributed under the terms of the Creative Commons Attribution NonCommercial License (https://creativecommons.org/licenses/by-nc/4.0) which permits unrestricted noncommercial use, distribution, and reproduction in any medium, provided the original work is properly cited.

\section{INTRODUCTION}

Treatment of colorectal cancer has gradually improved worldwide over the past few decades. Korea was the most successful country at increasing the survival of patients with colorectal cancer between 2011 and 2015 [1]. Due to advancements in chemotherapy, radiotherapy, and surgical techniques, more sphincter-saving surgeries using a colorectal or coloanal anastomosis without a permanent stoma have been performed for patients with rectal cancer. However, patients who underwent radical surgery for rectal cancer often suffer from low anterior resection syndrome (LARS) and symptoms such as frequent bowel movements, gas incontinence, fecal incontinence, fragmentation, and urgency [2-5]. 
Improved quality of life (QoL) and oncologic outcomes are important metrics for survivors of rectal cancer. Many patients who undergo surgery for rectal cancer experience LARS, and a number of studies reported that bowel habit changes affect patient QoL [6-8]. Until Emmertsen et al. [2] developed the LARS score in 2012, there were no evaluation tools or questionnaires for fecal incontinence and QoL that showed feasibility or validity for direct evaluation of LARS. The LARS score accurately reflects severity of bowel dysfunction after rectal surgery by scoring symptoms of LARS. The LARS score questionnaire was developed in Danish and was validated in many languages including English, Swedish, Spanish, Dutch, Japanese, and Chinese [9-12]. However, there has been no validated Korean version of the LARS score questionnaire until now. The aim of this study was to investigate the convergent validity, discriminative validity, and reliability of the Korean version of the LARS score questionnaire.

\section{METHODS}

\section{Questionnaire}

The LARS score is composed of five items: (1) incontinence for flatus, (2) incontinence for liquid stools, (3) frequency of bowel movements, (4) clustering of stools, and (5) urgency [2]. Each item has 3 or 4 response choices that are assigned with different score values. The range of score values was 0 to 42 with limits of 0 to 20 (no LARS), 21 to 29 (minor LARS), and 30 to 42 (major LARS). We received permission from Emmertsen et al. to translate the English version of the LARS score questionnaire into Korean. The translation was performed according to the forwardand-back translation method and followed the recommendations of the World Health Organization and the European Organisation for Research and Treatment of Cancer (EORTC) $[13,14]$. Two independent translators whose native language is Korean translated the English version of the LARS score into Korean. After the two translators reached an agreement, a common version was backtranslated to English by a third independent translator whose native language is English. Additional explanations for confusing words were inserted in parentheses in the final Korean version because "less than once" could be misunderstood in the Korean language. "Less than once" is usually regarded as "no or zero" in Korean. Appendix 1 shows the final Korean version of the LARS score questionnaire. One anchor question to assess QoL was added to the last part of the questionnaire ("Overall, how much does your bowel function affect your QoL?"), as previous studies suggested [9-11]. Available responses were "No"/"A little"/"Some"/ "A lot."

\section{Patients}

Between January and December 2018, patients who underwent radical surgery for rectal cancer at five institutions in Korea answered the Korean version of the LARS score questionnaire, including an anchor question. Participants were retested once more after 2 weeks. All participants had undergone a curative total mesorectal excision for rectal adenocarcinoma less than $15 \mathrm{~cm}$ from the anal verge. Only patients who had no stoma at the time of answering the questionnaire were eligible, including those who previously received stoma takedown (repair). Patients who had undergone abdominoperineal resection or palliative surgery were excluded. Patients who underwent surgery or examinations that could affect bowel function in the time between test and retest were also excluded to prevent test-retest reliability bias.

This study was conducted in compliance with the principles of the Declaration of Helsinki. The study protocol was reviewed and approved by the Institutional Review Boards of participating institutions (IRB No. of the principal investigator: KHNMC 201710-009-001). Written informed consents were obtained.

\section{Convergent validity}

Associations among the three groups based on the LARS score (no, minor, and major) and the three groups from the QoL impact anchor question responses (no, a little $=$ minor, some $/$ a lot $=$ some $/$ major) were analyzed for convergent validity. A 3-by-3 table was created to assess correlation between the LARS groups and the QoL groups. The percentages of perfect fit, moderate fit, and no fit were calculated. We hypothesized that the severity of the LARS score and influence on QoL would match. Therefore, when "no LARS" matched with "no affect to QoL," a perfect fit was achieved. A mismatch in one or two categorical levels was regarded as moderate fit or no fit, respectively. Moreover, differences in LARS score and QoL as continuous variables were also investigated.

\section{Discriminative validity}

Discriminative validity was assessed by comparing groups using the LARS score as a continuous variable: sex, age (more or less than 70 years), presence of stoma, time using the anus (i.e., time since radical surgery without stoma or reversal surgery of temporary stoma, less than or greater than 18 months), tumor location (higher or lower than $8 \mathrm{~cm}$ from the anal verge), and radiotherapy.

\section{Test-retest reliability}

Agreement between the first and second responses was investigated as perfect, moderate, and no agreement. The same response for both the first and second test was regarded as perfect agreement. A difference of one category or two categories was regarded as moderate or no agreement, respectively. The extent of agreement was demonstrated on a Bland-Altman plot. In addition, the intraclass correlation coefficient (ICC) of each question was assessed.

\section{Statistical analyses}

The sample size was calculated according to the rule that at least 10 to 15 patients per question should be recruited for appropriate analysis in the questionnaire survey [15]. The difference in convergent validity was analyzed via linear association and the Spear- 
man correlation coefficient. Additionally, the median value and interquartile range (IQR) were represented as a box plot, and the difference was assessed by Kruskal-Wallis and Mann-Whitney Utests for convergent and discriminative validity. For test-retest reliability, the extent of agreement was demonstrated on a BlandAltman plot and the ICC of each question was assessed. All statistical analyses were performed with the IBM SPSS ver. 24.0 (IBM Corp., Armonk, NY, USA) and R software packages (R version 3.5.1, www.r-project.org).

Table 1. Patient and treatment characteristics

\begin{tabular}{lc}
\hline Variable & Value \\
\hline Male sex & $107(73.3)$ \\
Age $(\mathrm{yr})$ & $62(28-78)$ \\
Body mass index $\left(\mathrm{kg} / \mathrm{m}^{2}\right)$ & $23.5(17.5-30)$ \\
Distance from anal verge $(\mathrm{cm})$ & $8(1-15)$ \\
Stoma & $69(47.3)$ \\
Time using the anus (mo) & $17(0.5-127)$ \\
Without stoma & $22(0.5-127)$ \\
After stoma takedown & $15(0.5-88)$ \\
Medication for LARS & $51(34.9)$ \\
Time between first and second tests (day) & $14(11-26)$ \\
\hline
\end{tabular}

Values are represented as number (\%) or median (range).

LARS, low anterior resection syndrome.

Table 2. Convergent validity

\begin{tabular}{lllc}
\hline Variable & No QoL & Minor QoL & Some/major QoL \\
\hline No LARS (0-20) & $12(8.2)$ & $25(17.1)$ & $9(6.1)$ \\
Minor LARS (21-29) & $0(0)$ & $16(11.0)$ & $20(13.7)$ \\
Major LARS (30-42) & $1(0.7)$ & $10(6.8)$ & $53(36.3)$ \\
LARS score as a continuous variable & $5(0-16)^{\mathrm{a}}$ & $21(13-29)^{\mathrm{b}}$ & $33(27-39)^{\mathrm{c}}$ \\
\hline
\end{tabular}

Values are represented as number (\%) or median (interquartile range).

LARS, low anterior resection syndrome; QoL, quality of life.

Perfect fit 55.5\%, moderate fit 37.6\%, no fit 6.8\%. P-values: a vs. b, 0.006; a vs. c, $<0.001$; and b vs. c, $<0.001$.

\section{RESULTS}

\section{Patients}

During the study period, 173 patients were asked to answer the Korean version of the LARS score questionnaire. Among them, 146 patients $(84.4 \%)$ completed the questionnaire twice. Patient and treatment characteristics are listed in Table 1 . The median age was 62 years, and the median tumor location was $8 \mathrm{~cm}$ from the anal verge. According to the LARS score, 46 patients had no LARS (31.5\%), 36 had minor LARS (24.7\%), and 64 had major LARS (43.8\%).

\section{Convergent validity}

For QoL categorization, perfect, moderate, and no fit were $55.5 \%$, $37.6 \%$, and $6.8 \%$, respectively $(\mathrm{P}<0.001)$ (Table 2$)$. The median LARS scores for no impact on QoL, minor impact on QoL, and some/major impact on QoL significantly differed at 5, 21, and 33, respectively (Fig. 1).

\section{Discriminative validity}

Male sex, tumor location less than $8 \mathrm{~cm}$ from the anal verge, and radiotherapy showed a significantly lower LARS score (Fig. 2). The LARS score was not different between patients grouped according to age, presence of stoma, and time using the anus.

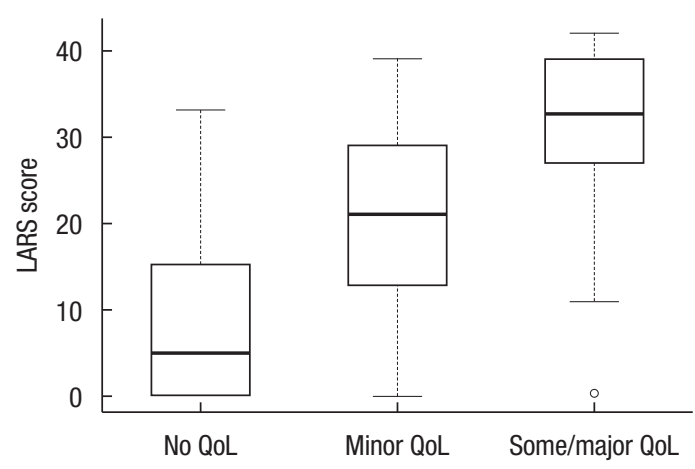

Fig. 1. c score versus impact in quality of life (QoL).
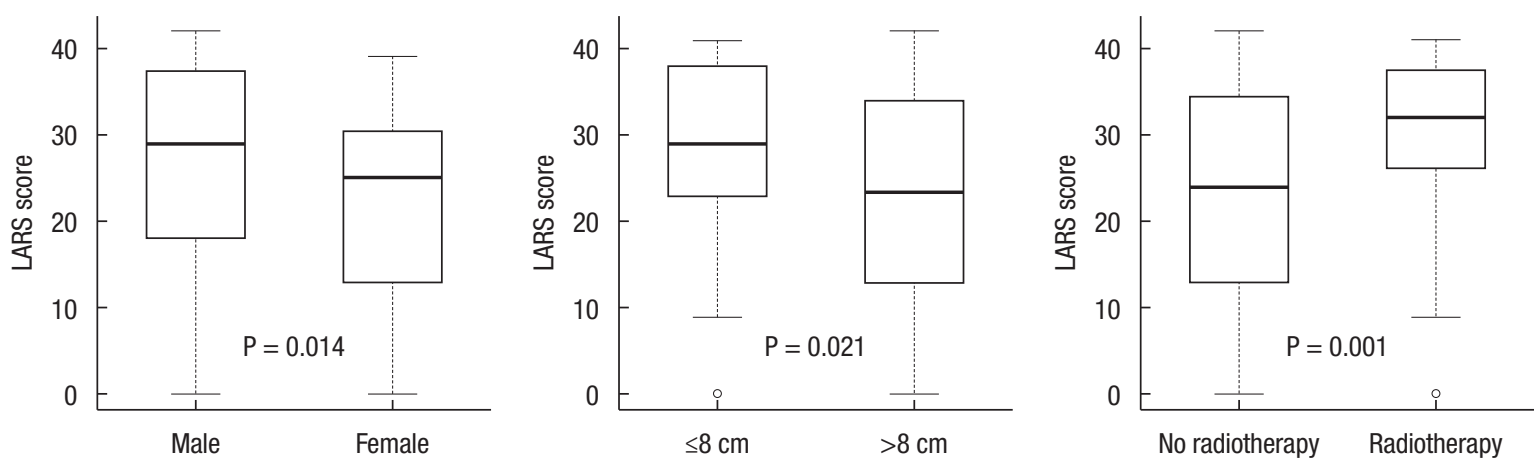

Fig. 2. Box plots comparing low anterior resection syndrome (LARS) score by sex, tumor location, and radiotherapy. 
Table 3. Test-retest reliability (\%)

\begin{tabular}{ccccc}
\hline Variable & Perfect fit & Moderate fit & No fit & ICC $(95 \%$ Cl $)$ \\
\hline LARS category & 88.3 & 10.9 & 0.7 & - \\
Item 1 & 87.6 & 9.6 & 2.8 & $0.932(0.906-0.951)$ \\
Item 2 & 85.6 & 11.0 & 3.4 & $0.909(0.874-0.935)$ \\
Item 3 & 86.3 & 13.1 & 0.7 & $0.944(0.923-0.960)$ \\
Item 4 & 91.1 & 6.9 & 2.1 & $0.931(0.904-0.950)$ \\
Item 5 & 85.6 & 13.7 & 0.7 & $0.942(0.920-0.958)$ \\
\hline
\end{tabular}

LARS, low anterior resection syndrome; ICC, intraclass correlation coefficient; Cl, confidence interval.

\section{Test-retest reliability}

For overall LARS category, perfect fit was $88.3 \%$ (Table 3). Each of the five items showed a high proportion of perfect fit $(85.6 \%-$ 91.1\%). The ICCs ranged from 0.909 to 0.944 , demonstrating high agreement. Fig. 3 illustrates the extent of agreement between LARS scores on the first and second tests via the Bland-Altman plot.

\section{DISCUSSION}

This study validated the Korean version of the LARS score questionnaire in Korean patients with rectal cancer. The LARS score questionnaire translated from English to Korean demonstrated convincing psychometric properties regarding convergent validity, discriminative validity, and reliability, in accordance with previous validation studies.

Perfect, moderate, and no fit were $55.5 \%, 37.6 \%$, and $6.8 \%$, respectively, between the LARS and QoL groups for convergent validity (Table 3). The LARS score was clearly associated with QoL in Korean patients, and these results are similar to studies from Europe and Japan. Juul et al. [9] reported that there were 4.3\% "no fits" in Sweden, 6\% "no fits" in Spain, 7.7\% "no fits" in Germany, and 2.3\% "no fits" in Denmark. However, Akizuki et al. [11] reported only $0.7 \%$ "no fits"; "perfect" and "moderate fit" were similar to our results (52.9\% and $46.3 \%$, respectively). Previous studies demonstrated that bowel dysfunction after rectal surgery is highly associated with poor QoL $[7,8,16]$. These studies analyzed the correlation of LARS score with EORTC Quality of Life Questionnaire-Core 30 and/or the Wexner incontinence score. Based on these results, surgeons can actively, rather than passively, help patients improve their QoL.

We sought to assess discriminative validity by identifying the correlation between the LARS score and known variables that might affect bowel dysfunction, including gender, age, presence of stoma, time using the anus, tumor location, and radiotherapy. Male gender, lower tumor location, and radiotherapy were related with lower LARS score in this study. In the European population, age, radiotherapy, and type of surgery (total vs. partial mesorectal excision) showed differences in the LARS score $[9,10]$. However, we could not analyze the type of surgery as in the European vali-

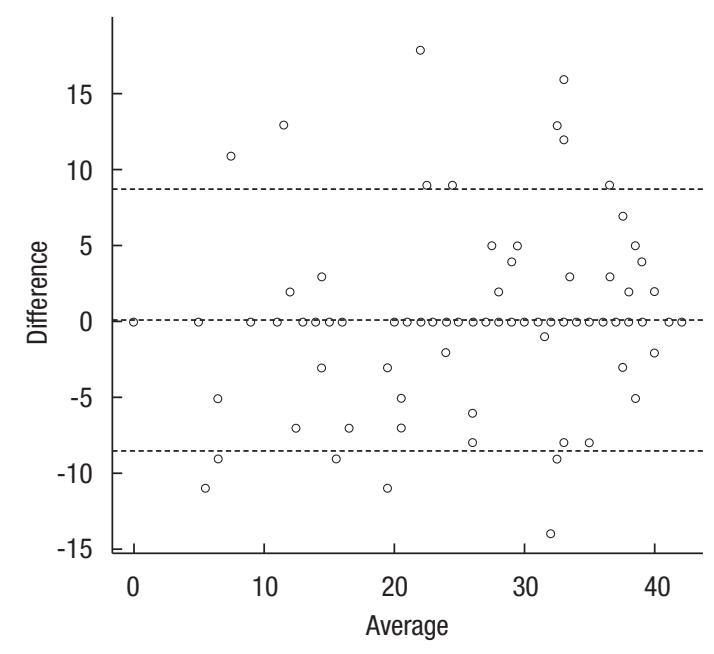

Fig. 3. Bland-Altman plot $95 \%$ limits of agreement (-8.5 to 8.8 ) illustrating differences between low anterior resection syndrome scores at first and second tests.

dation study because the concept of partial mesorectal excision was unfamiliar. This was similar to a Japanese validation study which classified the type of surgery as (low) anterior resection, ultra-low anterior resection, and intersphincteric resection because the concept of partial mesorectal excision is relatively new in Japan [11]. Limitations of their study included a study population from a single center and use of few neoadjuvant therapies. Hou et al. [12] demonstrated that female gender, radiotherapy, longer length of postoperative period, and lower tumor level were related to a lower LARS score in Chinese patients. Conversely, patients younger than 66.5 years old reported higher LARS scores than older patients with borderline significance $(\mathrm{P}=0.051)$. Although female gender is related to poor bowel dysfunction, our results may be due to confounding factors. There were several differences between male and female patients in our dataset, including age (62 years vs. 60 years), radiotherapy (37.4\% vs. $28.2 \%$ ), and time using the anus (15 months vs. 24 months); male patients tended to have poorer factors, which may be responsible for the higher LARS scores.

In terms of test-retest reliability, we found relatively higher agreement (perfect fit more than $85 \%$ for all items) compared with European and Japanese studies. These results could be due to our strict time interval requirements between the first and second tests. Because bowel preparation for colonoscopy or any surgery under general anesthesia can influence the reliability of the test, patients who were scheduled to receive procedures or surgery were excluded. Accuracy and simplicity of translation were also important to achieving reliability; the self-reported questionnaire was easily understood by the non-medical population.

This is the first multicenter study to validate the Korean version of the LARS score questionnaire under permission of the original authors. Physicians, nurses, and students can now freely use this 
Korean version of the LARS score questionnaire without contacting us. We hope that this questionnaire will assist in educating medical personnel and helping patients who suffer from LARS.

In conclusions, the Korean version of the LARS score questionnaire has proven to be a valid and reliable tool for measuring LARS in Korean patients with rectal cancer. This questionnaire is helpful for colorectal surgeons to improve treatment strategies for patients who suffer from LARS.

\section{CONFLICT OF INTEREST}

No potential conflict of interest relevant to this article was reported.

\section{ACKNOWLEGDMENTS}

This work was supported by a National Research Foundation of Korea (NRF) grant funded by the Korean Government Ministry of Education (No. 2017R1D1A1B03030948).

\section{REFERENCES}

1. Allemani C, Matsuda T, Di Carlo V, Harewood R, Matz M, Niksic $\mathrm{M}$, et al. Global surveillance of trends in cancer survival 2000-14 (CONCORD-3): analysis of individual records for 37513025 patients diagnosed with one of 18 cancers from 322 populationbased registries in 71 countries. Lancet 2018;391:1023-75.

2. Emmertsen KJ, Laurberg S. Low anterior resection syndrome score: development and validation of a symptom-based scoring system for bowel dysfunction after low anterior resection for rectal cancer. Ann Surg 2012;255:922-8.

3. Bregendahl S, Emmertsen KJ, Lous J, Laurberg S. Bowel dysfunction after low anterior resection with and without neoadjuvant therapy for rectal cancer: a population-based cross-sectional study. Colorectal Dis 2013;15:1130-9.

4. Lee WY, Takahashi T, Pappas T, Mantyh CR, Ludwig KA. Surgical autonomic denervation results in altered colonic motility: an explanation for low anterior resection syndrome? Surgery 2008;143: 778-83.

5. Kim KH, Yu CS, Yoon YS, Yoon SN, Lim SB, Kim JC. Effectiveness of biofeedback therapy in the treatment of anterior resection syndrome after rectal cancer surgery. Dis Colon Rectum 2011;54:
1107-13.

6. Emmertsen KJ, Laurberg S; Rectal Cancer Function Study Group. Impact of bowel dysfunction on quality of life after sphincterpreserving resection for rectal cancer. Br J Surg 2013;100:137787.

7. Konanz J, Herrle F, Weiss C, Post S, Kienle P. Quality of life of patients after low anterior, intersphincteric, and abdominoperineal resection for rectal cancer: a matched-pair analysis. Int J Colorectal Dis 2013;28:679-88.

8. Juul T, Ahlberg M, Biondo S, Espin E, Jimenez LM, Matzel KE, et al. Low anterior resection syndrome and quality of life: an international multicenter study. Dis Colon Rectum 2014;57:585-91.

9. Juul T, Ahlberg M, Biondo S, Emmertsen KJ, Espin E, Jimenez $\mathrm{LM}$, et al. International validation of the low anterior resection syndrome score. Ann Surg 2014;259:728-34.

10. Juul T, Battersby NJ, Christensen P, Janjua AZ, Branagan G, Laurberg $\mathrm{S}$, et al. Validation of the English translation of the low anterior resection syndrome score. Colorectal Dis 2015;17:908-16.

11. Akizuki E, Matsuno H, Satoyoshi T, Ishii M, Usui A, Ueki T, et al. Validation of the Japanese version of the low anterior resection syndrome score. World J Surg 2018;42:2660-7.

12. Hou XT, Pang D, Lu Q, Yang P, Jin SL, Zhou YJ, et al. Validation of the Chinese version of the low anterior resection syndrome score for measuring bowel dysfunction after sphincter-preserving surgery among rectal cancer patients. Eur J Oncol Nurs 2015;19: 495-501.

13. World Health Organization. Process of translation and adaptation of instruments [Internet]. Geneva (Switzerland) World Health Organization; 2019 [cited 2020 Feb 10]. Available from: https:// www.who.int/substance_abuse/research_tools/translation/en/.

14. Bullinger M, Alonso J, Apolone G, Leplege A, Sullivan M, WoodDauphinee $S$, et al. Translating health status questionnaires and evaluating their quality: the IQOLA Project approach. International Quality of Life Assessment. J Clin Epidemiol 1998;51:91323.

15. Pett MA, Lackey NR, Sullivan JJ, Making sense of factor analysis: the use of factor analysis for instrument development in health care research. Thousand Oaks (CA): SAGE Publications; 2003.

16. Theodoropoulos GE, Papanikolaou IG, Karantanos T, Zografos G. Post-colectomy assessment of gastrointestinal function: a prospective study on colorectal cancer patients. Tech Coloproctol 2013; 17:525-36. 


\section{Coloproctology \\ Validation of Korean Version of Low Anterior Resection Syndrome Score Questionnaire \\ Chang Woo Kim, et al.}

Appendix 1. The Korean version of the low anterior resection syndrome score questionnaire

\section{저위전방절제술 증후군 한글 설문지(대한대장항문학회)}

이 설문지의 목적은 당신의 배변 기능을 평가하기 위한 것입니다. 각 질문에 대해 하나의 답만 표시하 시길 바랍니다. 일부 환자들의 증상은 매일매일 달라진다는 것을 알고 있으며 단 하나의 답을 선택하기 가 어려울 수도 있습니다. 우리는 당신의 일상 생활을 가장 잘 표현하는 하나의 답을 선택하시기를 추 천드립니다. 만약 당신의 배변 기능에 영향을 미칠 수 있는 감염을 최근에 않은 적이 있다면 감염으로 인한 증상을 고려하지 말고 평소 배변 습관을 반영하는데 집중해서 답변하시길 바랍니다.

1. 당신은 가스배출(방귀)을 조절할 수 없는 경우가 있었습니까?

$\square$ 아니요, 전혀 없음. 0

$\square$ 예, 일주일에 한 번 미만으로 있음(예를 들면 한 달에 1 3번 정도). 4

$\square$ 예, 적어도 일주일에 한 번 이상 있음.

2. 당신은 액체상태의 무른 변이 우연히 새어 나온 적이 있습니까?

$\square$ 아니요, 전혀 없음. 0

$\square$ 예, 일주일에 한 번 미만으로 있음(예를 들면 한 달에 1 3번 정도). 3

$\square$ 예, 적어도 일주일에 한 번 이상 있음. 3

3. 당신은 얼마나 자주 대변을 보십니까?

$\begin{array}{lr}\square \text { 하루 (24시간)에 7회 이상 } & 4 \\ \square \text { 하루 (24시간)에 4-7회 } & 2 \\ \square \text { 하루 (24시간)에 1-3회 } & 0 \\ \square \text { 하루 (24시간)에 1회 미만(예를 들면 2 3일에 한 번 정도) } & 5\end{array}$

4. 당신은 마지막 대변을 본 후 1 시간 이내에 다시 대변을 보아야 했던 적이 있습니까?

$\square$ 아니요, 전혀 없음.

$\square$ 예, 일주일에 한 번 미만으로 있음(예를 들면 한 달에 1 3번 정도). 9

$\square$ 예, 적어도 일주일에 한 번 이상 있음. 11

5. 당신은 급하게 화장실에 달려가야 할 정도의 강한 충동을 경험한 적이 있습니까?

$\square$ 아니요, 전혀 없음. 0

$\square$ 예, 일주일에 한 번 미만으로 있음(예를 들면 한 달에 1 3번 정도). 11

$\square$ 예, 적어도 일주일에 한 번 이상 있음. 16

각 질문의 점수를 합산함. 0-20: 없음. 21-29: 경증. 30-42: 중증. 